\title{
周辺及び指向性を持つ線量計によるふなばし三番瀬海浜の線量率測定 RADIATION MEASUREMENT USING DIRECTIONAL DETECTOR ON FUNABASHI SANBANZE BEACH
}

\author{
川西利昌*1, 大塚文和*2 \\ Toshimasa KAWANISHI and Fumikazu OTSUKA
}

\begin{abstract}
In summer, a lot of swimmers come to the beach. The swimmers are exposed to radiation by the radioactivity of the beach. They want to know the exposure dose by the radiation. New directional measuring instrument is developed for the exposure dose. The exposure dose on beach was measured using the ambient dosimeter and directional detector. From measuring results on Funabashi Sanbanze beach, it is clear that the dose of trees planted to prevent sand is highest and of beach line is lowest. The dose of radioactivity of the sandy beach was half of the trees. It reduces an exposure dose that the people using the sandy beach spend at the place that is near to the beach line.
\end{abstract}

Keywords: Radiation, Beach, Dosimeter, Directional 放射線，海浜，線量計，指向性

\section{1. 緒論}

海浜は海水浴、散歩、スポーツなど年間を通じて沢山の人々に親 しまれている。また海浜は海浜休憩所や海洋リゾート施設など海洋 建築空間の場でもある。しかしながら 2011 年 3 月の福島第一原子 力発電所からの放射性物質排出によって、空気中に放射性物質が浮 遊して、大地に降下寸ると同時に、河川を通じて海に放射性物質が 流れ込み、海浜もその影響を受けている。

海洋の放射性物質拡散については津旨らによって研究が行われ ており、電力中央研究所報告に発表されている ${ }^{1)}$ 。また東京湾の放 射性物質については、大塚らによって大気及び主要河川からの流入 量が定量的に推定されており ${ }^{2)}$ 、文部科学省による現地調查も進行 している ${ }^{3), 4)}$ 。これらはいずれも海浜から離れた海底土、海水中の 放射性物質に関するものである。海浜については地方公共団体や研 究者によって放射線測定が実施されている ${ }^{5), 6), 7), 8) 。 ~}$

線量は国際放射線単位測定委員会 ICRUによって、「周辺線量」「方 向性線量」、「個人線量」が定義されている ${ }^{9)}$ 。このうち方向性線量 が入射方向に依存する量である。放射線被ばく防御の為に遮蔽物を 建設するならば、広い海浜のどの方向から放射線が入射しているか を知らなければならず、測定には指向性を持つ線量計を用いる必要 がある。

海浜を管理するためには、海浜の放射線量の実態を把握する必要 がある。本研究は海浜の空間線量率分布を知るため、全方位に感度
のある線量計と、新たに試作した指向性を持つ線量計とを用いて、 東京湾奥にあるふなばし三番瀬海浜において放射線を測定し、空間 線量率分布を明らかにしたものである。本研究により海浜での活動 時の放射線被ばく量の軽減、或いは放射線の遮蔽物を建設するため の資料を得る手段を提供できる。なお本研究では開口部のある遮蔽 箱に空間線量計を収納し、放射線の入射方向を限定した線量計を指 向性線量計と称した。

\section{2. 海浜の放射線}

福島第一原子力発電所事故により放出され、拡散した放射性物質 のほとんどは既に地表・地中や河床、あるいは海中・海底に移動し ていると考えられる。一方、河口域付近では、放射性物質の凝集等 の複雑な現象の中でホットスポットの形成が確認されている。河口 域や河口域付近の海浜等での放射性物質の詳細な実態が確認されて おらず、早急な把握が必要と考えられる。その結果によっては海浜 等での被ばくの可能性もあり、これらの場所での放射線影響につい ても検討する必要がある。

文部科学省は平成元年に発電用軽水炉原子炉施設の安全審査にお ける一般公衆の線量当量評価について告示・通達を行い ${ }^{10)}$ 、海洋関 連の被ばく経路について海上作業、遊泳、海浜作業、漁網操作、海 産物摂取について触れている。この内、海洋建築空間に関係するも のは主に遊泳、海浜作業である。河口など放射性物質が排出する近

\footnotetext{
*1 日本大学理工学部海洋建築工学科 特任教授 - 工博

Prof., Nihon University, Dr. Eng.

*2 日本大学理工学部海洋建築工学科 助教. 工博

Assist. Prof., Nihon University, Dr. Eng.
} 
傍は、放射性物質の沈着する地域が生じる。満潮時に放射性物質が 沈着し、干潮時に海浜が露出して放射線源となると記されている ${ }^{11}$ 本研究では海浜の放射線の検討に必要な基礎資料を得るため千葉県 船橋市ふなばし三番瀬海浜で線量率測定を行った。

\section{3. 海浜の線量率測定}

\section{1 線量計}

本測定で用いた HORIBA 社 PA-100 線量計(以下線量計と略称) は、 検出方式はシンチレーション式、測定線種は $\gamma$ 線、 $1 \mathrm{~cm}$ 線量当量率 表示、サンプリング時間 60 秒である。点状線源 (72664Bq)を用いた 校正を行った。IAEA 実効線量評価式を(1)に示寸 ${ }^{12)}$ 。

$$
E_{e x t} / T_{e}=A \times C F_{6} \times 0.5^{d / d 1 / 2} / X_{s}^{2}
$$

$E_{\text {ext }}$ は点状線源からの実効線量 $(\mathrm{mSv}), A$ は線源の放射能 $(\mathrm{kBq}), C F_{6}$ はセシウム 137 の換算計数 $(\mathrm{mSv} / \mathrm{h}) /(\mathrm{kBq}), T_{e}$ は被曝期間 $(\mathrm{h}), d_{1 / 2}$ は半価層 $(\mathrm{cm}), d$ は遮蔽厚 $(\mathrm{cm}), X_{s}$ は点状線源からの距離 $(\mathrm{m})$ を表す。 PA-100 を用いて点状線源からの距離 $30 \mathrm{~cm}$ から $70 \mathrm{~cm}$ まで $10 \mathrm{~cm}$ 間隔 と $90 \mathrm{~cm}$ で、各箇所 10 回測定し、その結果を表 1 に示した。評価式 值と測定值は図 1 に示すように一致している。線源から $70 \mathrm{~cm}$ を超す と、環境線量が $0.097 \mu \mathrm{Sv} / \mathrm{h}$ のため一定となった。図中に Tes-172 とあるのは日立アロカメディカル社の線量計で比較校正のため用い た。なお測定場所の環境線量率は $0.097 \mu \mathrm{Sv} / \mathrm{h}$ である。

以降、全方位からの線量率を測定する機器を単に線量計と称し、 測定した值を線量率と表現する。ある方向からの線量率を測定する 線量計を指向性線量計と称し、測定值を指向性線量率と称した。指 向性線量率の単位を $\mu \mathrm{Sv} / \mathrm{h}$ で表しているが、測定器の表示值を意味 する。

表 1 線源からの距離と線量率

\begin{tabular}{|c|c|c|c|c|c|c|}
\hline $\begin{array}{l}\text { 線源からの } \\
\text { 距離 } L(\mathrm{~cm})\end{array}$ & 30 & 40 & 50 & 60 & 70 & 90 \\
\hline 実測最大値 & 0.156 & 0.136 & 0.121 & 0.120 & 0.116 & 0.107 \\
\hline 実測平均値 & 0.146 & 0.128 & 0.114 & 0.114 & 0.106 & 0.100 \\
\hline 実測最小値 & 0.138 & 0.120 & 0.104 & 0.107 & 0.092 & 0.093 \\
\hline $\begin{array}{c}\text { 実効線量 } \\
\text { (含環境放 } \\
\text { 射線) }\end{array}$ & 0.145 & 0.126 & 0.116 & 0.110 & 0.107 & 0.103 \\
\hline 標準偏差 & 0.007 & 0.005 & 0.005 & 0.004 & 0.007 & 0.005 \\
\hline
\end{tabular}

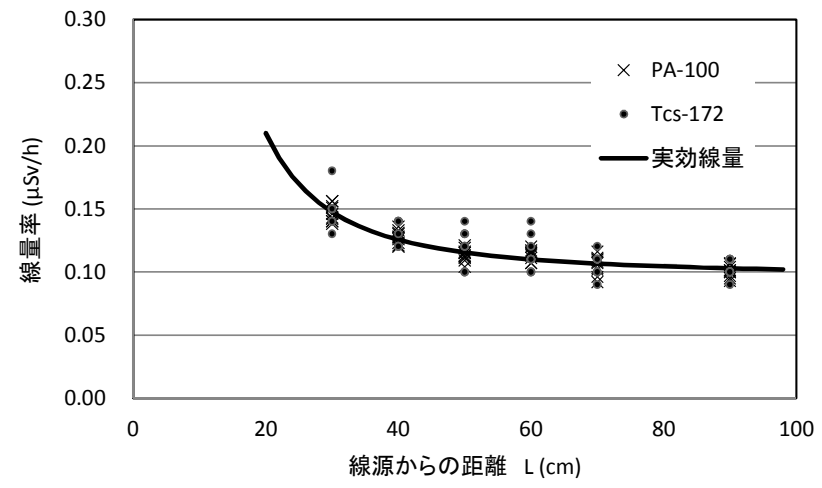

図 1 線源からの距離と線量率

\section{2 海浜各部の線量率測定結果}

線量率測定の対象とした千葉県船橋市ふなばし三番瀬海浜を図 2 , 図 3 に示す。緯度 35 度 41 分、経度 139 度 46 分に位置する。ここ で汀線の方位は N80W, S80E である。海浜長さは $1,130 \mathrm{~m}$ 、浜幅約 $50 \mathrm{~m}$ から $100 \mathrm{~m}$ で、砂質区分は細砂、中央粒径 $187 \mu \mathrm{m}$ である。防砂林は 4 群からなり、樹種はクロマツ、長さ合計 $360 \mathrm{~m} 、$ 幅 $16 \mathrm{~m}$ で、防砂林 から汀線に向かって約 $10 \mathrm{~m}$ 幅を持つ雑草群がある。測定月日時は 2012 年 5 月 23 日である。測定高さは地表 $5 \mathrm{~cm}$ 、各箇所で 4 回測定し、 平均値を測定值とし図 5、図 6, 図 8 から図 10 に測定結果を示す。位 置はGPS で測定した。図 4 は三番瀬海浜中央の航空写真、図 5 は三 番瀬海浜中央の線量率で、防砂林内部で $0.087 \mu \mathrm{Sv} / \mathrm{h}$ から $0.130 \mu$ $\mathrm{Sv} / \mathrm{h}$ 、海浜中央で $0.076 \mu \mathrm{Sv} / \mathrm{h}$ から $0.097 \mu \mathrm{Sv} / \mathrm{h}$ 、汀線付近で 0.033 $\mu \mathrm{Sv} / \mathrm{h}$ から $0.036 \mu \mathrm{Sv} / \mathrm{h}$ となり、防砂林内部は汀線付近の 3 倍程度 となる。

図 6 は防砂林内部、砂浜中央、砂浜汀線付近の、汀線に平行な線 量率分布である。三番瀬海浜防砂林西端を基点としている。防砂林 内部が高く最大 $0.128 \mu \mathrm{Sv} / \mathrm{h}$ 、平均 $0.11 \mu \mathrm{Sv} / \mathrm{h}$ 、最小 $0.087 \mu \mathrm{Sv} / \mathrm{h}$ の線量率が測定された。砂浜中央の平均值は $0.086 \mu \mathrm{Sv} / \mathrm{h}$ 、砂浜汀 線付近の平均值は $0.035 \mu \mathrm{Sv} / \mathrm{h}$ である。防砂林内部は、砂浜汀線付 近の 3 倍以上であった。汀線と海浜両端の砂の線量率は、沖合の海 底から打ち上げられる放射性物質や海中に溶け込んでいる放射性物 質、また海浜両端の突堤外側にある河口の川底にある放射性物質や 河川から海に流入する河川水に含まれる放射性物質などにより定ま る。

図 7 は三番瀬海浜東側の航空写真，図 8 は三番瀬海浜東側の線量 率で防砂林内部は $0.068 \mu \mathrm{Sv} / \mathrm{h}$ から $0.123 \mu \mathrm{Sv} / \mathrm{h}$ 、海浜中央で 0.029 $\mu \mathrm{Sv} / \mathrm{h}$ から $0.085 \mu \mathrm{Sv} / \mathrm{h}$ 、汀線付近で $0.030 \mu \mathrm{Sv} / \mathrm{h}$ から $0.032 \mu \mathrm{Sv} / \mathrm{h}$ 、 と防砂林内部は汀線の 2 から 3 倍である。夏季、海水浴客は三番瀬 海浜中央部から汀線にかけて、日除けを設置し、滞在するので放射 線被ばくから考えると、海浜の中では被ばく量が少ない箇所にいる と云える。図 9 は三番瀬海浜東側の、汀線に平行な線量率分布であ

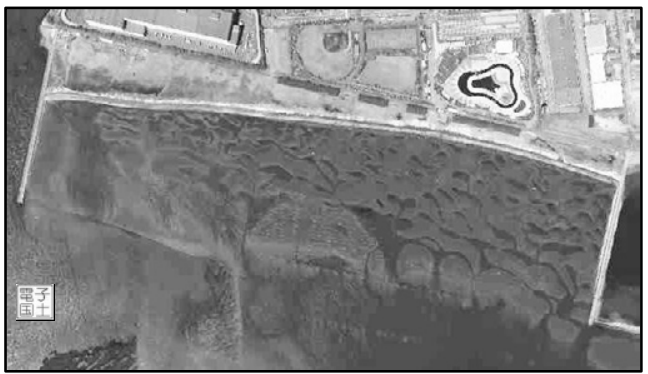

図 2 千葉県船橋市ふなばし三番瀬海浜 ${ }^{13}$

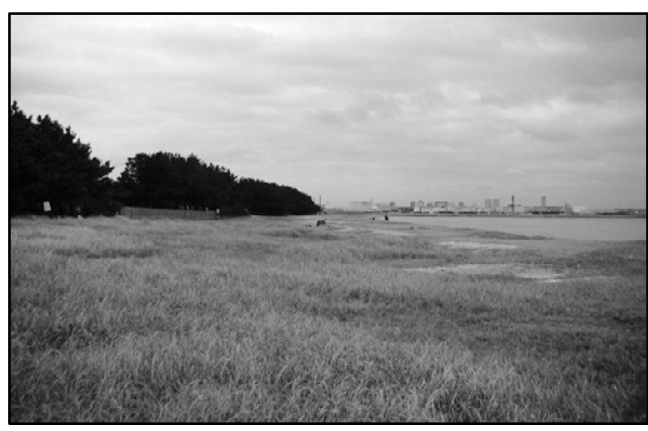

図 3 三番瀬海浜の防砂林・雑草・砂浜・汀線の写真 


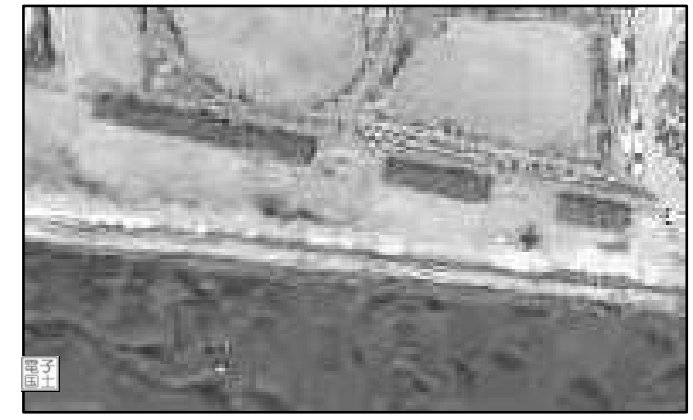

図 4 三番瀬海浜中央の航空写真 ${ }^{13)}$

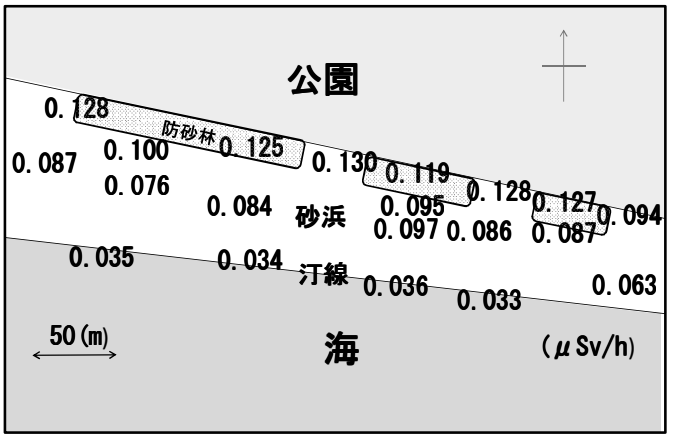

図 5 三番瀬海浜中央の空間線量率分布

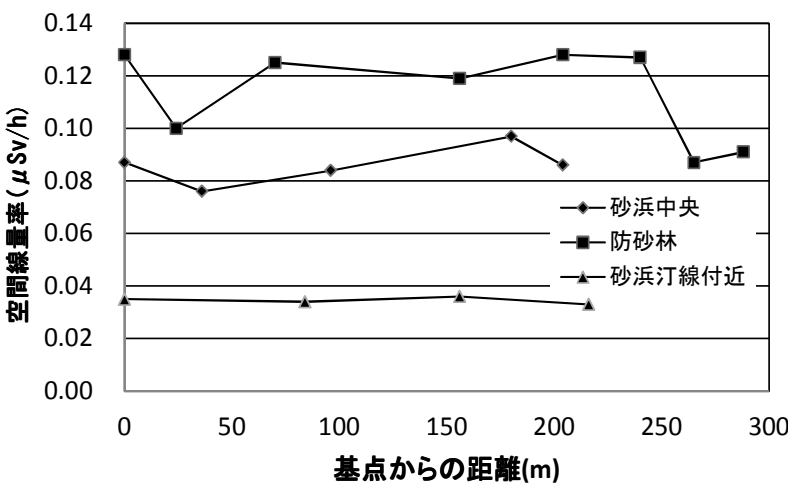

図 6 三番瀬海浜西端からの距離と汀線方向の空間線量率分布

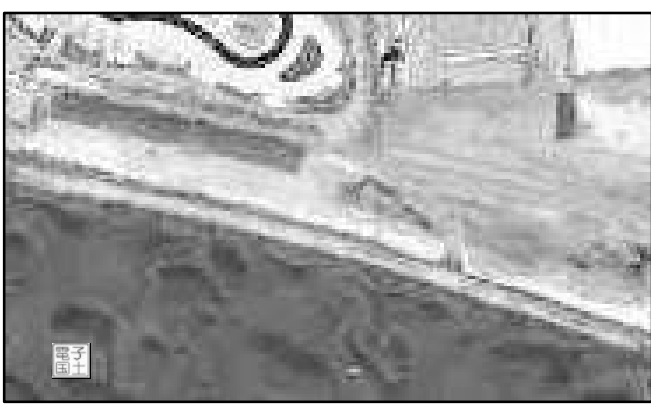

図 7 三番瀬海浜東側の航空写真 ${ }^{13)}$

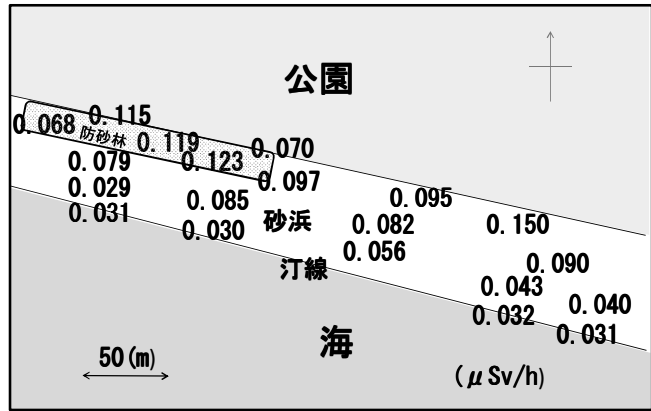

図 8 三番瀬海浜東側の空間線量率分布

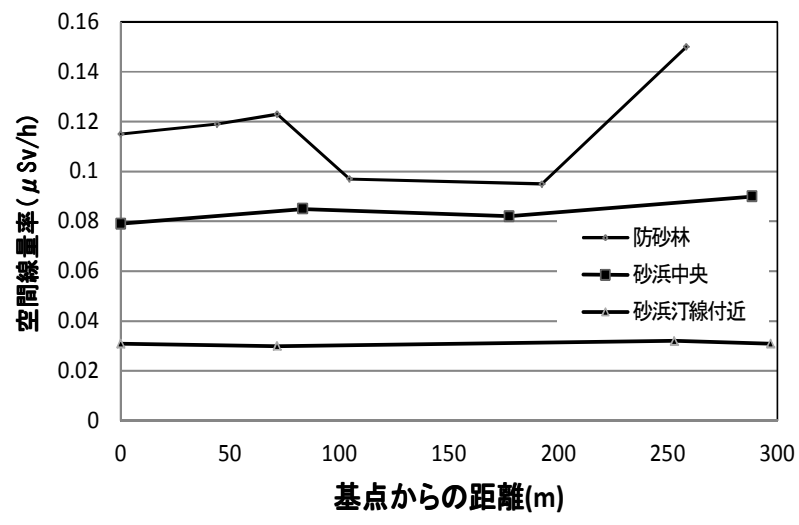

図 9 三番瀬海浜西端を基点とした距離と線空間量率分布

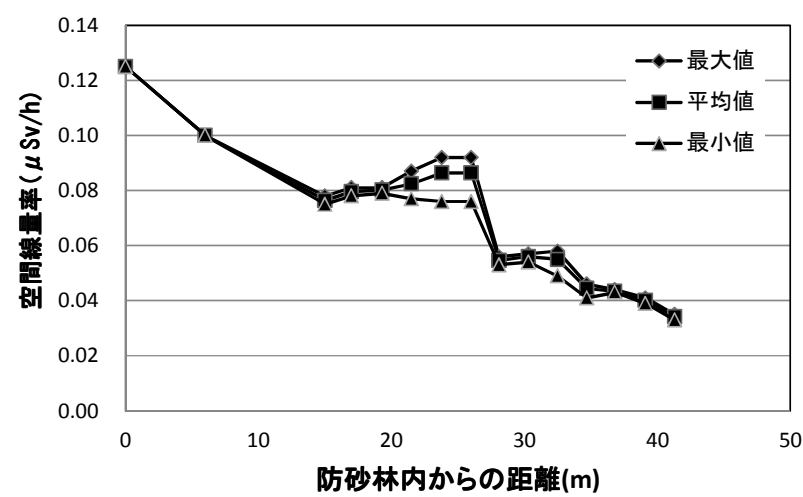

図 10 防砂林内から汀線に向かう方向の空間線量率分布

る。三番瀬海浜中央と同様な傾向をしめしており、防砂林で最も高 く、砂浜中央、汀線付近の砂浜と線量率は低くなる。図 10 は防砂林 内から汀線に向かう方向の線量率分布である。横軸の $0 \mathrm{~m}$ 位置は防砂 林に近い海浜で、線量率が高く、また $10 \mathrm{~m}$ までは雑草が砂上に存在 し、放射線源となっている。17m は砂のみで線量率が急激に減少し、 汀線近い $25 \mathrm{~m}$ は雑草付近と比較して線量率は半減し、海浜上で最も 低い線量率となる。2012 年 5 月のふなばし三番瀬海浜公園管理者の 砂上 $50 \mathrm{~cm}$ におけるの線量率は $0.032 \mu \mathrm{Sv} / \mathrm{h}$ から $0.047 \mu \mathrm{Sv} / \mathrm{h}$ であり、 本測定值の範囲に入っている ${ }^{6)}$ 。

\section{3 汀線付近砂浜の空間線量率の経日変化}

図 11 は汀線付近の砂浜を、汀線に平行に 10 籄所を測定点とした 線量率の経日変化である。 5 月 23 日、 6 月 5 日、 7 月 30 日、10 月 27 日、11月 10 日の 5 回にわたって測定した。汀線付近の砂浜のた

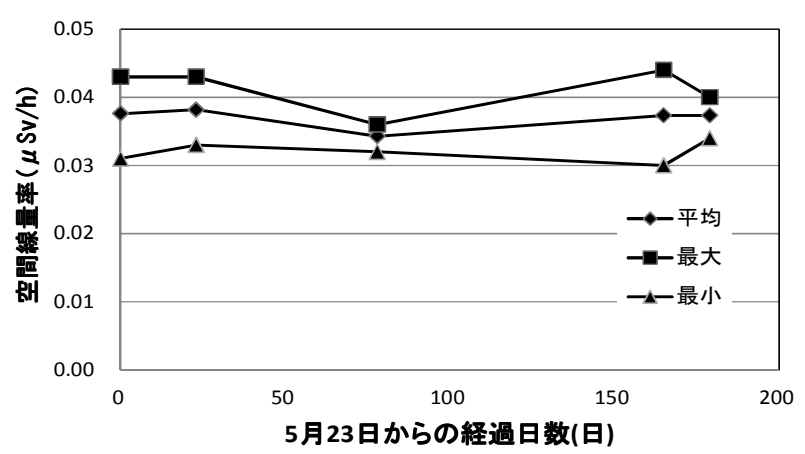

図 11 三番瀬海浜汀線付近砂浜の経日変化 
め、満潮には海水に浸り、干潮時には空気に曝される。また放射性 物質は気中を降下したもの、周囲の砂の海水による打ち上げなど、 波浪や潮流等、複雑な原因を持ち、減少や増加の一定な傾向はみら れないが、 $0.03 \mu \mathrm{Sv} / \mathrm{h}$ から $0.45 \mu \mathrm{Sv} / \mathrm{h}$ の間を増減している。

\section{4. 海浜の指向性線量率測定}

\section{1 指向性線量計}

今回の測定では線量計を全方向と一方向の 2 種類の使い方をした。 通常の線量計は周囲からセンサーに入射する放射線を測定する。し たがって指向性は尖鋭的でなく、放射線を入射方向別に測定するに は適切でない。そこで線量計を 1 方向に開口部を持つ放射線遮蔽箱 に入れ、一方向のみの線量率を測定できるようにした。方向性を持 つ線量計は三上らによっても開発され研究に利用されている ${ }^{14)}$

図 12,13 は厚み $2 \mathrm{~cm}$ の鉛でできた放射線遮蔽箱である。開口部は 水平方向面にあり、中心に円空が設けられている。図 14 のように空 の直径は $2 \mathrm{~cm}, 3 \mathrm{~cm}, 4 \mathrm{~cm}$ の 3 種類を用意したが、ここでは $3 \mathrm{~cm}, 4 \mathrm{~cm}$ の ものを用いた。開口角はそれぞれ 54 度、68 度、立体角はそれぞれ $0.68 \mathrm{sr} 、 1.07 \mathrm{sr}$ である。

図 15 は校正のための線源と指向性線量計の位置を示す。図 16 は 遮蔽箱開口部と線量計先端部の距離と線量率である。開口部は解放 とした。この距離が長いほど指向性の高い線量計が作れる。しかし

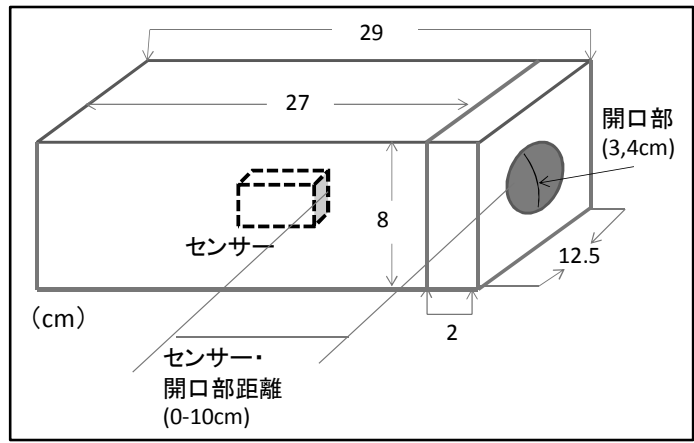

图 12 指向性線量計の遮蔽箱

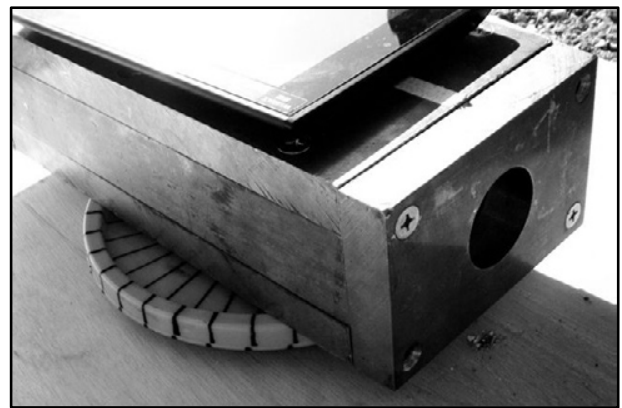

図 13 指向性線量計遮蔽箱の外観

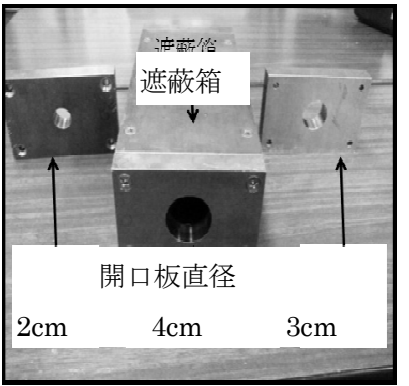

図 14 遮蔽箱と開口板

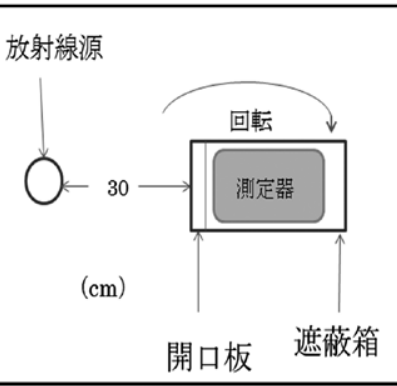

図 15 線源と指向性線量計
実測の結果、距離を長く取ると線量率が半減し、測定値が小さくな り精度が低くなることが判ったので、距離は 0 にすることにした。 指向性測定は点放射線源 Cs137 から $30 \mathrm{~cm}$ にセンサーを置き、水平 回転角度 0 度から 90 度、180 度まで 10 度毎に行った。実験パラメ ータは開口円空の直径と、開口円空からセンサー迄の距離、遮蔽箱 の方向である。各角度で 5 回測定し、平均值を測定值とした。図 17、 図 18 は指向性測定結果で、開口円空が大きいほど感度は高いが半值 角が大きい。開口円空からセンサーまでの距離が長いほじ、感度は 低くなるが、半值角は小さくなる。これらの測定結果から、海浜の 現場では、感度が高く、半值角が小さく指向性が確保できる開口円 空直径 $4 \mathrm{~cm}$ 、開口円空とセンサー間距離 $0 \mathrm{~cm}$ を採用した。

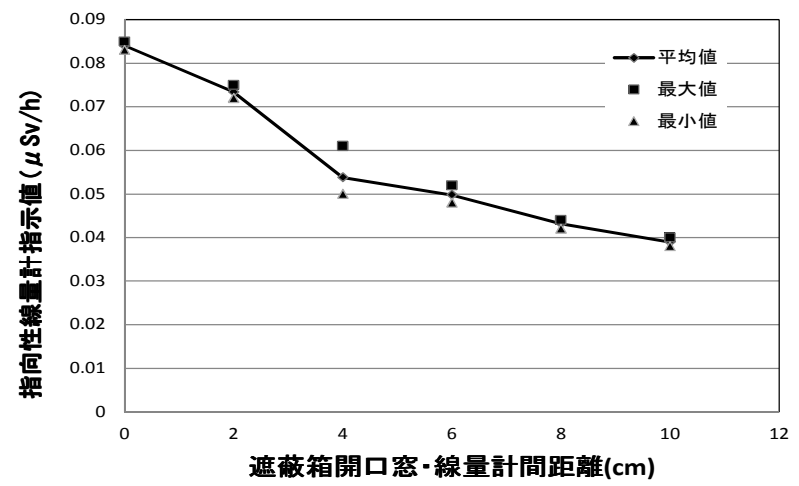

図 16 遮蔽箱開口円空・指向性線量計間距離

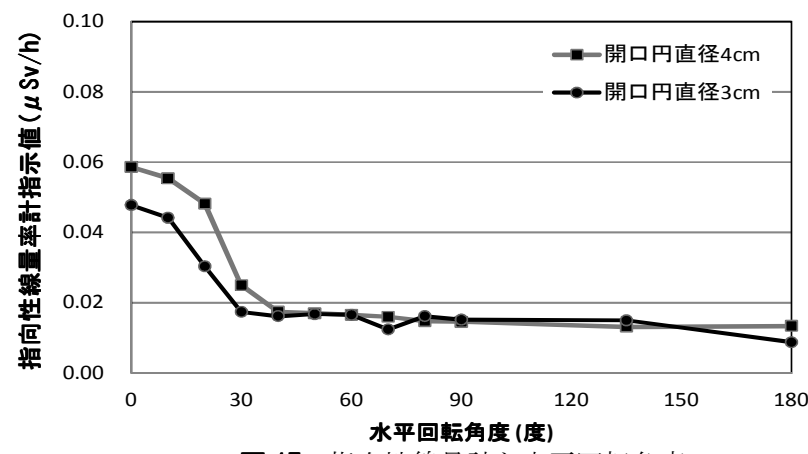

図 17 指向性線量計と水平回転角度

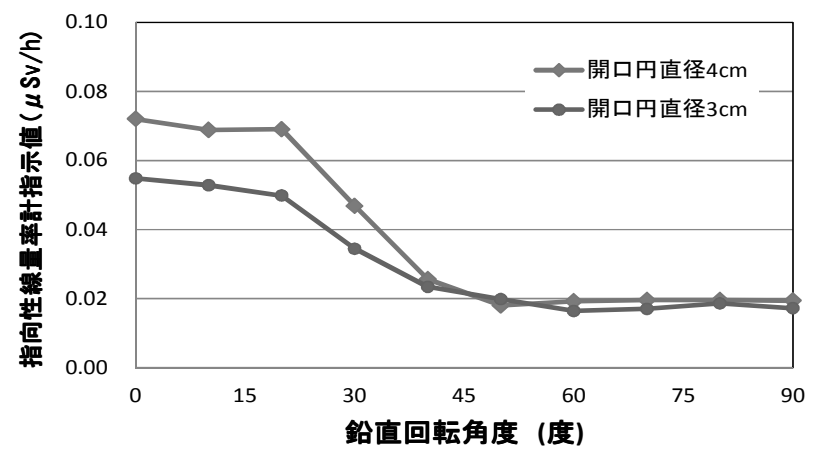

図 18 指向性線量計と鉛直回転角度

\section{2 海浜の指向性線量率分布測定}

海浜上の方向別の線量率を 2012 年 12 月 30 日、汀線付近、海浜中 央、防砂林付近砂浜で測定した。指向性線量計を砂上高さ $28 \mathrm{~cm}$ に設 置し、0 度を測定点から海側に向から方向として、10 度毎に 180 度 時計回りに水平回転させた。各地点、各角度で 10 回測定し、平均し 


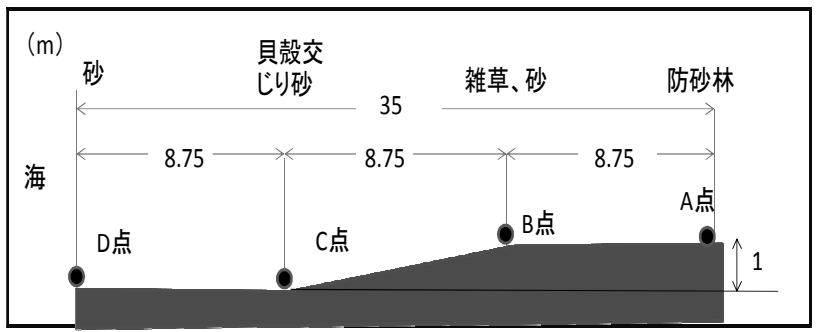

図 19 三番瀬海浜断面

て実測值とした。図 19 は測定点である。図 20 に各地点での測定結 果と、測定点における汀線に平行な方向の魚眼写真を示す。円グラ フの 0 度は海側、180 度は陸側である。指向性線量計は魚眼写真内 の矢印のように海側から陸側に回転した。横軸は指向性線量率の最 も大きい防砂林の值を基準として相対量で表示し、相対指向性線量 率とした。D 点は汀線付近で、0 度付近で相対指向性線量率 0.4 をし めし、途中凹凸はあるが陸に向からにつれて指向性線量率は増え、 0.55 と 1 割以上増加している。魚眼写真の上半分は空、下半分は砂
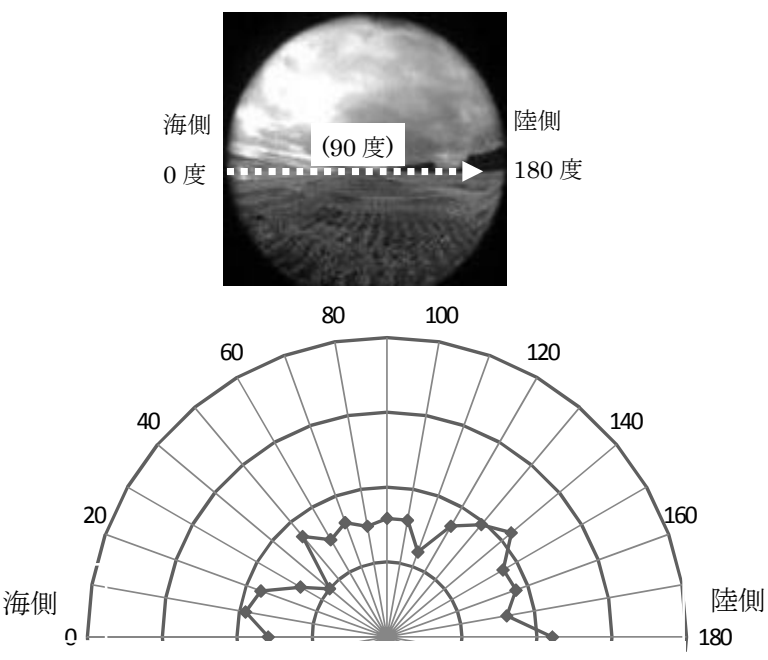

$\begin{array}{lllllllll}1.0 & 0.75 & 0.5 & 0.25 & 0 & 0.25 & 0.5 & 0.75 & 1.0\end{array}$

(i) D 点 砂浜汀線の相対指向性線量率
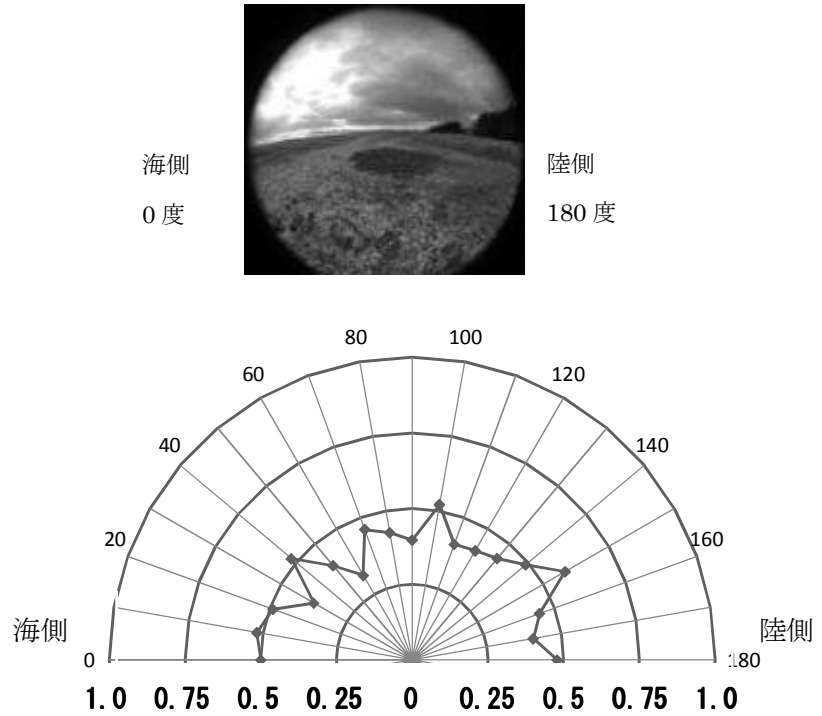

（ii） $\mathrm{C}$ 点 貝殼交じり砂浜の相対指向性線量率

図 20 各地点の水平回転方向の相対指向性線量率
浜で放射線はここから来ている。

$\mathrm{C}$ 点は汀線から約 $9 \mathrm{~m}$ 、防砂林端部から $17 \mathrm{~m}$ である。貝殼交じりの 砂で、全方向の相対指向性線量率はほぼ 0.4 から 0.5 である。B 点 は貝殼交じりの砂上であるが、陸側に枯草があるため 150 度から 160 度にかけて 0.75 に達する。A 点は枯れた雑草上で、50 度から 120 度まで 0.75 以上と大きく、170 度から 180 度は防砂林の影響で 1 と 海浜で最大となる。防砂林、枯れた雑草の存在によって指向性線量 率は高くなり、砂だけの場合低くなり、海に向かう側は極めて低い ことが分かった。

図 21 は相対指向性線量率と水平回転角度で表現したグラフであ る。防砂林側の砂浜端は相対指向性線量率が他の倍近い。角度が 180 度に近くなるにつれて大きくなるのは線量率の高い防砂林や雑草が 180 度側に存在寸るからである。線の凹凸が各所にあるが、地点の 周囲の地面の凹凸や雑草の有無による。

指向性線量計の開発によって、従来、放射線の入射する方向と大 きさが判らなかったものが測定可能になった。したがって放射線被 ばくを防ぐための行動や、遮蔽物の設計が容易になる。
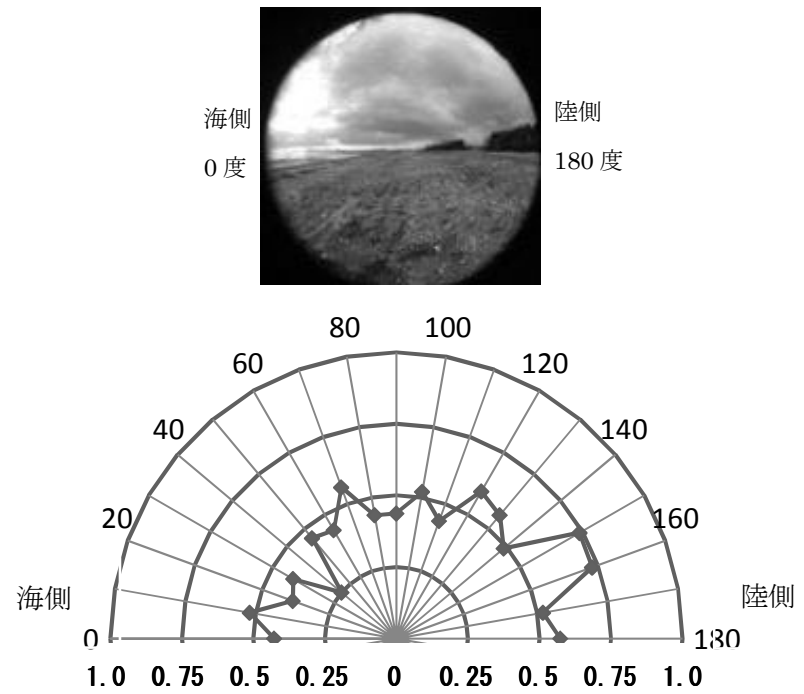

(iii) $\mathrm{B}$ 点 雑草、砂浜の相対指向性線量率
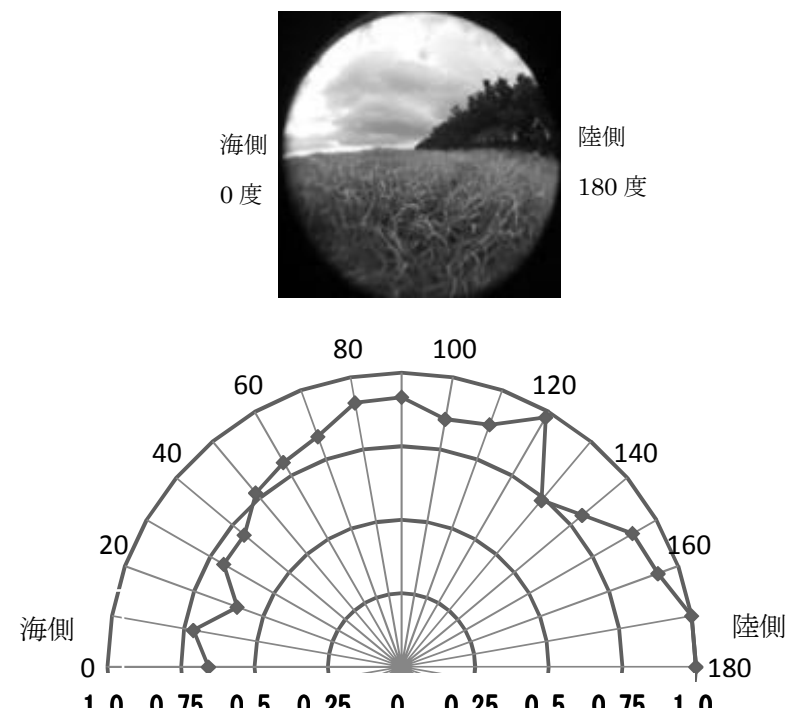

(iv) $\mathrm{A}$ 点 防砂林端の相対指向性線量率 


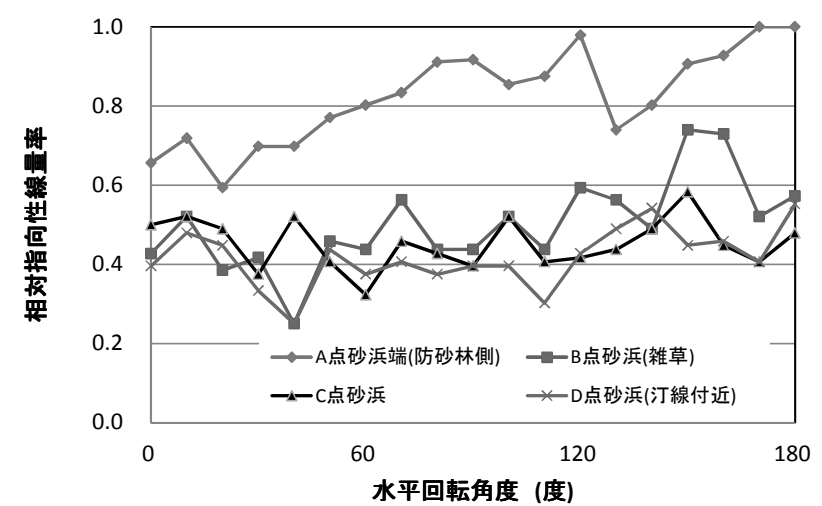

図 21 相対指向性線量率と水平回転角度

\section{5. 結論}

本研究は次のようにまとめられる。

(1) 周辺を測る線量計で三番瀬海浜中央の空間線量率を測定した結 果、防砂林内部で $0.087 \mu \mathrm{Sv} / \mathrm{h}$ から $0.130 \mu \mathrm{Sv} / \mathrm{h}$ 、海浜中央で 0.076 $\mu \mathrm{Sv} / \mathrm{h}$ から $0.097 \mu \mathrm{Sv} / \mathrm{h}$ 、汀線付近で $0.033 \mu \mathrm{Sv} / \mathrm{h}$ から $0.036 \mu \mathrm{Sv} / \mathrm{h}$ となり、防砂林内部は汀線付近の 3 倍程度となる。

(2)汀線付近の砂浜を、汀線に平行に 10 箇所を測定点とした空間線 量率の経日変化は、減少や増加の一定な傾向はみられないが、0.03 $\mu \mathrm{Sv} / \mathrm{h}$ から $0.045 \mu \mathrm{Sv} / \mathrm{h}$ の間を増減した。

（3）線量計を 1 方向に円空開口部を持つ放射線遮蔽箱に入れて指向 性を持つ空間線量計を製作した。空の直径は $4 \mathrm{~cm}$ 、開口角は 68 度、 立体角は $1.07 \mathrm{sr}$ 、半減角は全角 60 度である。汀線付近、海浜中央、 防砂林付近砂浜で水平に回転させて測定した結果、防砂林の方向の 指向性線量率は高く、海に向かう側の倍あることが分かった。

\section{謝辞}

本研究は本学早川建教授、早川恭史准教授に測定・分析の指導を 賜った、厚くお礼申し上げる次第である。測定を行った本学卒研生 大野、海寶、木村君に感謝寸る。

\section{参考文献}

1) 津旨大輔、坪野考樹、青山道夫、廣瀬勝巳 : 福島第一原子力発電所から漏 洩した ${ }^{137} \mathrm{C}_{\mathrm{s}}$ の海洋拡散シミュレーション、電力中央研究所報告 V11002、 pp. 1-18、2011.11

2) 大塚文和、廣實信人、川西利昌、増田光一 : 東京湾を対象とした福島第一 原子力発電所事故に伴う放射性物質の流入量の推定、土木学会論文集第 68 巻第 4 号、B3-124、2012.6

3) 文部科学省 : 東京湾における海域モニタリング結果(海底土)、2012.8

4) 文部科学省ほか : 平成 24 年度海域モニタリングの進め方、2013.3

5) N. Fujinami1, T. Koga and H. Morishima : External Exposure Rates from Terrestrial Radiation at Guarapari and Meaipe in Brazil,

http://www. irpa. net/irpa10/cdrom/00490. pdf、2013年3月15日参照

6) 船橋市 : ふなばし三番瀬海浜公園潮干狩場の放射能測定について、2013.2 http://www. park-funabashi. or. jp/bay/houshanoukeka/ など、2013 年 4 月 8 日参照

7) R. Veigaa, etc: Measurement of natural radioactivity in Brazilian beach sands, Radiation Measurements 41 pp. 189-196, 2006

8) A. S. Alencar*, A. C. Freitas: Reference levels of natural radioactivity for the beach sands in a Brazilian southeastern coastal region,
Radiation Measurements 40, pp. 76-83, 2005

9）国際放射線単位測定委員会（ICRU）（13-01-03-11）被ばく管理のための 種々の線量 (09-04-02-05), http://www. rist. or. jp/atomica/data/dat_ detail. php?Title_Key=09-04-02-05、2013 年 3 月 15 日参照

10）文部科学省 : 発電用軽水型原子炉施設の安全審査における一般公衆の線 量当量評価について、p. 14、1988. 3

11）文部科学省 : 発電用軽水型原子炉施設の安全審査における一般公衆の線 量当量評価について、p. 15

12）放射線医学総合研究所緊急被ばく医療研究センター線量評価研究部訳 : Generic Procedures for Assessment and Response during Radiological Emergency (国際原子力機関 (IAEA) 放射線緊急事態時の評価および対応の ための一般的手順)、IAEA-TECDOC-1162、p. $86,2000.3$

13）国土交通省国土地理院（写真）

http://archive. gsi. go. jp/airphoto/ViewPhotoServlet?workname=CKT200 $92 \&$ courseno $=C 35 \&$ photono=19、2013 年 3 月 15 日参照

14) Satoshi MIKAMI: Performance Test in Terms of Energy and Angular Dependence with ISO Photon Radiation on an Ambient and Directional Dose Equivalent Rate Meter、RADIOISOTOPES, 54, pp545-553 ,2005

（2013年 4 月10日原稿受理，2013年10月 7 日採用決定） 